\title{
SEROLOGICAL PROFILE OF ANTI-Toxoplasma gondii ANTIBODIES IN APPARENTLY HEALTHY DOGS OF THE CITY OF BOTUCATU, SÃO PAULO STATE, BRAZIL
}

\author{
LANGONI H. (1), MODOLO J. R. (1), PEZERICO S. B. (1), SILVA R. C. (1),
} CASTRO A. P. B. (1), DA SILVA A. V. (1), PADOVANI C. R. (2)

(1) Department of Veterinary Hygiene and Public Health, School of Veterinary Medicine and Animal Husbandry (FMVZ), São Paulo State University, UNESP, Botucatu, São Paulo, Brazil; (2) Department of Biostatistics, Biosciences Institute, São Paulo State University, UNESP, Botucatu, São Paulo, Brazil.

ABSTRACT: Toxoplasmosis is a zoonosis caused by Toxoplasma gondii, a coccidian protozoan of worldwide distribution. The seroprevalence in canine population can be an alternative for measuring T. gondii urban spreading. A total of 780 blood samples from dogs were collected, during the yearly anti-rabies campaign, carried out by the Department of Veterinary Hygiene and Public Health, School of Veterinary Medicine and Animal Husbandry (FMVZ), São Paulo State University, UNESP, together with the county health authorities, in August 1999. Using Indirect Fluorescent Antibody Test (IFAT) for detecting antibodies anti-T. gondii in the sera samples, we observed that 258 dogs (33.1\%) were positive. The associations between the serological results and the epidemiological variables were studied. Statistically significant differences were not found regarding sex (32.2\% male and 34.3\% female reactors). Dogs without a defined breed showed seropositivity statistically higher than the pedigreed group. The occurrence of infection was considered higher with age.

KEY WORDS: Toxoplasma gondii, dog, serology.

\section{CORRESPONDENCE TO:}

H. LANGONI, Departamento de Higiene Veterinária e Saúde Pública, Faculdade de Medicina Veterinária e Zootecnia, UNESP, Distrito de Rubião Jr., s/n, Caixa Postal 560, 18.618-000, Botucatu, SP, Brasil. Phone: 55143811 6270. Fax: 55143811 6075. Email: hlangoni@fmvz.unesp.br 
$\mathrm{H}$. Langoni et al. SEROLOGICAL PROFILE OF ANTI-Toxoplasma gondii ANTIBODIES IN APPARENTLY HEALTHY DOGS OF THE CITY OF BOTUCATU, SÃO PAULO, STATE BRAZIL. J. Venom. Anim. Toxins incl. Trop. Dis., 2006, 12, 1, p.143

\section{INTRODUCTION}

Toxoplasmosis is one of the most common parasitic zoonosis caused by a coccidian protozoan, whose life cycle alternates between an intermediate and a definitive host, in which the sexual form appears. In the intermediate host, usually herbivorous or omnivorous, the parasite multiplies in several cell types, culminating in the formation of tissue cysts. In the definitive host, members of several species of the Felidae family, the sexual phase causes the formation of oocysts in the gut. Man and animals can be infected by the three forms of the parasite: by ingestion of sporulated oocysts eliminated in the feline feces; by ingestion of cysts in tissues of the intermediate host; and by transplacental transmission of tachyzoites. Toxoplasma gondii can also be transmitted by blood, organ transplant, or by ingestion, such as in unpasteurized goat's milk (24).

Humans and dogs, in postnatal life, are usually infected by ingestion of sporulated oocysts found in nature, or by ingestion of cysts in raw or poorly cooked meat of an intermediate host. However, it is not known which of these routes are epidemiologically more important. It is probable that the main sources of infection by T. gondii for man may be different because of cultural and food habits (24). The incidence of toxoplasmosis in urban areas can be related to environmental contamination with oocysts. A direct measurement of this environmental contamination by oocysts is unfeasible due to technical reasons. An interesting alternative for measuring the $T$. gondii urban spreading is the seroprevalence in freeliving urban animals, once they are exposed to similar risks of Toxoplasma infection, like humans (16).

Serological researches have indicated that up to $90 \%$ of dogs can be exposed to $T$. gondii infection, and that they can be sharing with man the same sources of infection, probably food (6). The prevalence of $T$. gondii in humans, dogs, cats, and other animals from farms in the north of Paraná State was studied. Considering titer 16 as positive in the IFAT, anti-Toxoplasma gondii antibodies were found in $65.8 \%$ of humans, $73 \%$ of cats, and $84.1 \%$ of dogs tested. The relationships human-canine, human-feline, and canine-swine show some epidemiological significance, which may be related to the possibility that those species share the same sources of infection, suggesting food as a common factor for humans and dogs (9).

Rolling in or ingestion of cat feces, containing oocysts of $T$. gondii, by dogs could contaminate the domestic environment, thus exposing their owners to infection (8). It 
$\mathrm{H}$. Langoni et al. SEROLOGICAL PROFILE OF ANTI-Toxoplasma gondii ANTIBODIES IN APPARENTLY HEALTHY DOGS OF THE CITY OF BOTUCATU, SÃO PAULO, STATE BRAZIL. J. Venom. Anim. Toxins incl. Trop. Dis., 2006, 12, 1, p.144

was demonstrated that after ingestion of non-sporulated oocysts of $T$. gondii, these can pass through the intestinal tract of dogs and be excreted in an infective stage, meaning that dogs can act as mechanical vectors of the oocysts (15).

The aim of this study was to investigate the serological profile of healthy dogs to $T$. gondii in the city of Botucatu, São Paulo State, Brazil, and to compare the occurrence of the infection in relation to sex, breed, and age.

The blood samples collected during the yearly campaign for anti-rabies vaccination, which was done by the county health authorities together with the Department of Veterinary Hygiene and Public Health, School of Veterinary Medicine and Animal Husbandry (FMVZ), São Paulo State University (UNESP), Botucatu, São Paulo, Brazil. Out of 45 stations, 14 were selected at random. The number of samples was determined by considering an error factor of $10 \%$, with a 95\% confidence level. Out of the 780 samples collected from apparently healthy dogs, 453 were from male dogs, 327 from female dogs, 568 were from dogs without a defined breed, and 212 from pedigreed dogs, aged from 3 months to 20 years.

Sera were tested by IFAT for anti-Toxoplasma gondii IgG antibodies (3), using a canine anti-lgG antibody conjugated to fluorescein isothiocyanate, kindly supplied by the Center for Zoonosis Control of São Paulo City Hall. In all tests, positive and negative control sera were examined. Readings were carried out in a fluorescent Zeiss microscope, model SH 250, considering positive the serum reacting at dilutions equal or higher than 1:16.

The associations between the result of the serological exam and the epidemiological variations were studied according to the Goodman test $(11,12)$ for contrast among multinomial populations. For studying the existence of preferential systematized distribution, according to categories of age, breed, and sex, the chi-square test was used for sampling, with a significance level of 5\% (22).

From the 780 samples, 258 (33.1\%) showed anti-T. gondii antibodies. The most frequent titer was 16, in 134 (52.6\%) dogs, followed by titer 64, in 110 (42.4\%), and titer 256, in 14 (5.5\%) dogs. There was no significant difference in the occurrence of anti-T. gondii antibodies, with 146 (32.2\%) male and 112 (34.3\%) female reactors. Statistical analysis demonstrated that there was a significant difference between the groups of pedigreed dogs and without a defined breed. The animals without a defined breed presented a higher prevalence (35.9\%) than pedigreed dogs (25.5\%). In this study, the occurrence of infection was higher with age (Table 1). 
H. Langoni et al. SEROLOGICAL PROFILE OF ANTI-Toxoplasma gondii ANTIBODIES IN APPARENTLY HEALTHY DOGS OF THE CITY OF BOTUCATU, SÃO PAULO, STATE BRAZIL. J. Venom. Anim. Toxins incl. Trop. Dis., 2006, 12, 1, p.145

As demonstrated by seroepidemiological studies in different parts of the world, $T$. gondii infection is common in dogs, with prevalence ranging from $20 \%$ to $91 \%(1,2)$. This study showed a lower prevalence of antibodies to $T$. gondii (33.1\%) as compared to other studies performed in Brazil, showing 91\% (10), 63.8\% (14), and $50.5 \%$ (16).

The literature shows variable values of prevalence that can be related to the dilution and the tests used $(2,4,13,17,18,20,21)$. These differences can be expected, due to geo-climatical regional characteristics and epidemiological factors, such as numbers of infected felines in the studied area, age and management of animals, cultural aspects, and sanitary practices in the community (5).

With relation to the sex, there was no significant difference in the prevalence of infection, which agrees with other studies $(2,4,7,10,14,18,19,23)$. On the other hand, there was a significant difference regarding breed, with a higher prevalence in dogs without defined breed, what is in agreement with other results $(2,17,18)$. This fact suggests that these animals are more exposed to risk factors of $T$. gondii infection, such as contaminated food and cat feces, and to the social patterns of their owner that can afford, or not, food of better quality and in more quantity for his/her dogs (17).

The infection was higher with age (Table 1), and it is possible, because the ingestion of raw or poorly cooked meat, containing cysts of $T$. gondii, increases with time (18, 23). Chances of infection can increase with age due to the higher exposition. Similar results were observed by other authors $(2,4,7,10,13,18)$.

The results of this study suggest that infection by $T$. gondii is endemic in dogs of Botucatu, São Paulo State, indicating that the parasite can be disseminated in the urban area, demonstrating the risk to the human population, because both dogs and man can be exposed to common sources of this infection. 
H. Langoni et al. SEROLOGICAL PROFILE OF ANTI-Toxoplasma gondii ANTIBODIES IN APPARENTLY HEALTHY DOGS OF THE CITY OF BOTUCATU, SÃO PAULO, STATE BRAZIL. J. Venom. Anim. Toxins incl. Trop. Dis., 2006, 12, 1, p.146

Table 1. Occurrence of anti-Toxoplasma gondii antibodies confirmed by indirect fluorescent antibody test in dogs from Botucatu, São Paulo State, Brazil, according to age, in 2004.

\begin{tabular}{ccc}
\hline Age (years) & Samples & Reactive samples \\
\hline $0.25-3.3$ & 448 & $132(29.5 \%)$ \\
$3.4-6.6$ & 192 & $71(37.0 \%)$ \\
$6.7-9.9$ & 87 & $25(28.7 \%)$ \\
$10-13.2$ & 32 & $16(50.0 \%)$ \\
$13.3-20$ & 5 & $3(75.0 \%)$ \\
No data & 16 & $11(68.7 \%)$ \\
\hline Total & 780 & $258(33.1 \%)$ \\
\hline
\end{tabular}

\section{REFERENCES}

1 BJÖRRKMAN C., LUNDÉN A., UGGLA A. Prevalence of antibodies to Neospora caninum and Toxoplasma gondii in Swedish dogs. Acta Vet. Scand., 1994, 35, 445-7.

2 CABRAL DD., SILVA DAO., MINEO JR., FERREIRA FA., DURAN FP. Frequency of anti-Toxoplasma gondii antibodies in apparently healthy dogs of the city of Uberlândia - MG. Rev. Bras. Parasitol. Vet., 1998, 7, 87-90.

3 CAMARGO ME. Introdução às técnicas de imunofluorescência. Rev. Bras. Patol. Clin., 1964, 10, 143-71.

4 CANON-FRANCO WA., BERGAMASCHI DP., LABRUNA MB., CAMARGO LM., SILVA JC., PINTER A., GENNARI SM. Occurrence of anti-Toxoplasma gondii antibodies in dogs in the urban area of Monte Negro, Rondonia, Brazil. Vet. Res. Commun., 2004, 28, 113-8.

5 CHHABRA MB., GUPTA SL., GAUTAM OP. Toxoplasma seroprevalence in animals in Northern India. Int. J. Zoon., 1985, 12,136-42.

6 DUBEY JP. Toxoplasmosis in dogs. Canine Pract., 1985, 12, 7-28.

7 FREIRE RL., NAVARRO IT., VIDOTTO O., TUDURY EA., VIANNA CC. Prevalência de anticorpos anti-Toxoplasma gondii em cães atendidos no Hospital Veterinário da UEL - PR. Semina: Ci. Agrárias, 1992, 13, 65-9. 
8 FRENKEL JK., HASSANEIN KM., HASSANEIN RS., BROWN E., THULLIEZ P., QUINTEREO-NUÑEZ R. Transmission of Toxoplasma gondii in Panama City, Panama: a five year prospective cohort study of children, cats, rodents, birds, and soil. Am. J. Trop. Med. Hyg., 1995, 53, 458-68.

9 GARCIA JL., NAVARRO IT., OGAWA L., OLIVEIRA RC. Soroprevalência do Toxoplasma gondii, em suínos, bovinos, ovinos e equinos, e sua correlação com humanos, felinos e caninos, oriundos de propriedades rurais do Norte do Paraná - Brasil. Ciênc. Rural, 1999, 29, 91-7.

10 GERMANO PML., ISHIZUKA MM., ERBOLATO EB. Estudo sorológico da toxoplasmose canina pela prova de imunofluorescência direta, na cidade de Campinas, 1981. Rev. Fac. Med. Vet. Zoot. Univ. S. Paulo, 1985, 22, 53-8.

11 GOODMAN LA. Simultaneous confidence intervals for contrasts among multinomial populations. Ann. Math. Stat., 1964, 35,716-25.

12 GOODMAN LA. On simultaneous confidence intervals for multinomial proportions. Technometrics, 1965, 7, 247-54.

13 GUIMARÃES AM., RIBEIRO MFB., LIMA JD., CURY MC., SPIEWAK G. Freqüência de anticorpos anti-Toxoplasma gondii em cães de Belo Horizonte, Minas Gerais. Arq. Bras. Med. Vet. Zootec., 1992, 44, 67-8.

14 ISHIZUKA MM., YASUDA PH. Incidência de infecção por Toxoplasma gondii em cães do município de São Paulo. Rev. Fac. Med. Vet. Zoot. Univ. S. Paulo, $1981,18,161-5$.

15 LINDSAY DS., DUBEY JP., BUTLER JM., BLAGBURN BL. Mechanical transmission of Toxoplasma gondii oocysts by dogs. Vet. Parasitol., 1997, 73, 27-33.

16 MEIRELES LR., GALISTEO Jr. AJ., POMPEU E., ANDRADE Jr. HF. Toxoplasma gondii spreading in an urban area evaluated by seroprevalence in free-living cats and dogs. Trop. Med. Int. Health, 2004, 9, 876-81.

17 MINEO TWP., SILVA DAO., NÄSLUND K., BJÖRKMAN C., UGGLA A., MINEO JR. Toxoplasma gondii and Neospora caninum serological status of different canine populations from Uberlândia, Minas Gerais. Arq. Bras. Med. Vet. Zootec., 2004, 56, 414-7. 
18 NAVARRO IT., FREIRE RL., VIDOTTO O., OGAWA L., KANO FS. Estudo comparativo entre soro e plasma na pesquisa de anticorpos anti-Toxoplasma gondii pela técnica de imunofluorescência indireta em cães atendidos no Hospital Veterinário da Universidade Estadual de Londrina - PR, 1996. Semina: Ci. Agrárias, 1997, 18, 15-21.

19 RIEMANN HP., KANEKO JJ., HAGHIGHI S., BEHYMER DE., FRANTI CE., RUPPANNER R. The prevalence of antibodies against Toxoplasma gondii among hospitalized animals and stray dogs. Can. J. Comp. Med., 1978, 42, 407-13.

20 SALATA E., YOSHIDA EL., PEREIRA EA., CORREA FM. Toxoplasmosis in wild and domestic animals of the Botucatu region, State of São Paulo, Brazil. Rev. Inst. Med. Trop. S. Paulo, 1985, 27, 20-2.

21 SILVA DAO., CABRAL DD., BERNARDINA BLD., SOUZA MA., MINEO JR. Detection of Toxoplasma gondii - specific antibodies in dogs. A comparative study of immunoenzymatic, immunofluorescent and haemagglutination titers. Mem. Inst. Oswaldo Cruz, 1997, 92, 785-9.

22 STREINER DL., NORMAN GR. Biostatistics - The base essentials. St. Louis: Mosby-Year Book, 1994. 260p.

23 SVOBODA M., SVOBODOVÁ V. Effect of breed, sex, age, management and nutrition on the incidence of Toxoplasma gondii antibodies in dogs and cats. Acta Vet. Brno., 1987, 56, 315-30.

24 TENTER AM. Current knowledge on the epidemiology of infections with Toxoplasma. Tokai J. Exp. Clin. Med., 1999, 23, 391. 